\title{
Dynamics of nutrient concentrations and eutrophication of the waters in Barguzin Bay (Lake Baikal)
}

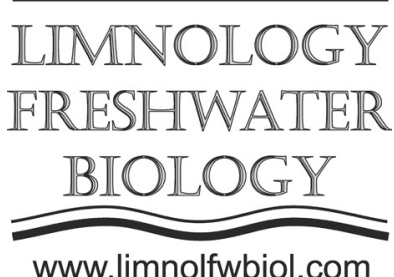

\author{
Sorokovikova L.M.*, Tomberg I.V., Sinyukovich V.N., Ivanov V.G. \\ Limnological Institute Siberian Branch of the Russian Academy of Sciences, Ulan-Batorskaya Str., 3, Irkutsk, 664033, Russia
}

\begin{abstract}
We present the results of long-term studies of the nutrient concentrations in the Barguzin River and Barguzin Bay. The bay has specifics in the spatial distribution as well as seasonal and interannual dynamics of the nutrient concentrations. In the interannual aspect, the concentrations of mineral forms of nutrients decreased in the bay. Based on the total phosphorus concentration, the water in Barguzin Bay is classified as slightly polluted.
\end{abstract}

Keywords: Barguzin Bay, nutrients, mineral and total phosphorus, water quality.

Anthropogenic eutrophication of lakes caused by enrichment of waters with nutrients at present has become an almost ubiquitous phenomenon, including the largest lakes. Baikal is the world's largest and deepest lake; its deep-water part occupies $93 \%$ of the total water area. Deltaic and estuarine shallows of the lake occupy the small area, have the highest productivity and are more susceptible to pollution (Timoshkin et al., 2014). Eutrophication of Barguzin Bay is largely due to the influx of nutrients with the waters of the Barguzin River (Drucker at al., 1997).

Comprehensive hydrological, hydrophysical and hydrochemical studies of the Barguzin River and Barguzin Bay were conducted in different seasons from 2004 to 2019.

The nutrient concentrations in the Barguzin River during the study period varied as follows: phosphate phosphorus - from 0.04 to $0.32 \mathrm{mgP} / \mathrm{L}$, total mineral nitrogen - from 0.04 to $0.85 \mathrm{mgN} / \mathrm{L}$ and silica - from 2.1 to $6.6 \mathrm{mgSi} / \mathrm{L}$. Their maximum concentration was recorded in winter, and the minimum concentration - in summer during the mass development of algae. When river waters enter the bay, the Baikal flow carries them away, and they are mainly distributed along its northeast coast, predetermining spatial dynamics of nutrient concentrations. The volume of river runoff, the influence of the waters of open Baikal and the level of phytoplankton development largely determine their seasonal and interannual changes. Analysis of seasonal dynamics of the phosphate phosphorus, total mineral nitrogen and silica concentrations has indicated an abrupt decrease in these concentrations within the first three kilometers from the estuary when the river waters enter the bay both in winter and during open water. Farther, the decrease is much slower, which was previously reported (Tomberg, 2008). However, in the winters of 2015 and 2016, the distribution pattern of the nitrogen, silica and phosphorus concentrations (Fig.) along the main flow of the river waters (right section) changed: after the decrease in the concentrations, at the station in located $0.5 \mathrm{~km}$ from the estuary, at onekilometer distance, we again recorded their increase, but farther, the concentrations decreased. We assume that at the $0.5 \mathrm{~km}$ station we recorded the Baikal water, the evidence of which is close concentrations of elements in the central and left sections as well as similar dynamics of mineralization and temperature of the water. Water mineralization in the Barguzin River was $185 \mathrm{mg} / \mathrm{L}$, at the $0.5 \mathrm{~km}$ station $110 \mathrm{mg} / \mathrm{L}$, at the one-km station - $179 \mathrm{mg} / \mathrm{L}$.

Farther than the three-kilometer station, the concentrations of nutrients in all sections corresponded to that in the water of open Baikal in winter. During open water, we normally recorded a decrease in these concentrations within the first three kilometers. The content in river waters determines seasonal changes in the concentrations of phosphate phosphorus (Fig.) and other nutrients in the mixing zone of river and lake waters: elevated values are recorded in winter, and minimum ones - in summer. Analysis of interannual changes in the concentrations of mineral forms of nutrients in the bay revealed their decrease in recent years, especially during open water, which is likely associated with intensive vegetation of phytoplankton, as evidenced by seasonal changes in the concentrations of total phosphorus, in which organic phosphorus now dominates. In winter, the concentration of total phosphorus varied from 12 to $46 \mu \mathrm{g} / \mathrm{L}$, increasing during spring and summer to $168-186 \mu \mathrm{g} / \mathrm{L}$ in the mixing zone and to $32-54 \mu \mathrm{g} / \mathrm{L}$ in open Baikal (the $11-\mathrm{km}$ station). The obtained results evidence the high trophicity of the waters in the bay, as indicated previously in (Watanabe and Drucker, 1999). Concerning the concentration of total phosphorus, the water quality in Barguzin bay according to the classification by (Oksiyuk et al., 1993) changes from "sufficiently clean" to "slightly polluted". 


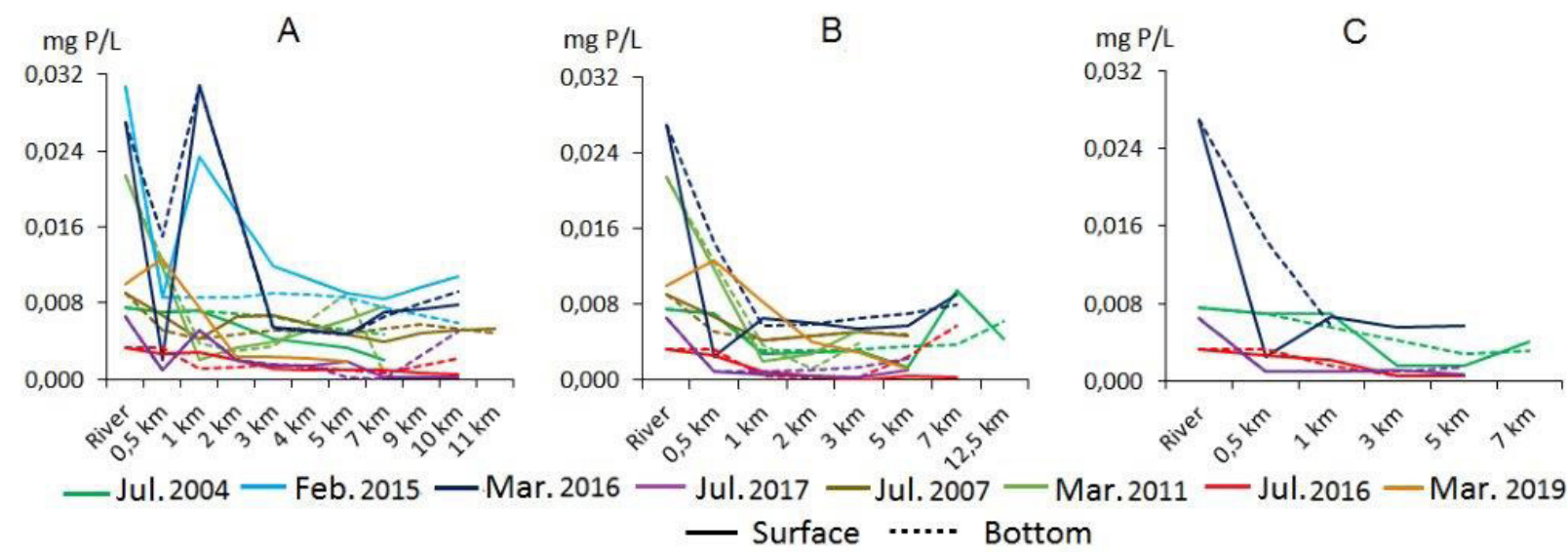

Fig. Dynamics of the concentrations of phosphate phosphorus in the water area of Barguzin Bay. A - right section, B - central section, $\mathrm{C}$ - left section.

\section{Conclusions.}

The conducted studies confirm the local distribution of the Barguzin River waters in Barguzin Bay limited to a three-kilometer area, evidence the growth of organic forms of nutrients in recent years and indicate the risk of eutrophication of Barguzin Bay.

The study was carried out within the framework of the LIN SB RAS State Task No. 0345-2019-0008 (AAAA-A16-1161 22110065-4).

\section{References}

Drucker V.V., Sorokovikova L.M., Sinyukovich V.N. et al. 1997. Water quality in the Barguzin River under current conditions. Geografiya i Prirodnyye Resursy [Geography and Natural Resources] 4: 72-78. (in Russian).
Oksiyuk O.P., Zhukinsky V.N., Braginsky L.P. et al. 1993. Integrated environmental classification of surface water quality. Gidrobiologicheskiy Zhurnal [Hydrobiological Journal] 4: 62-76. (in Russian)

Timoshkin O.A., Bondarenko N.A., Volkova E.A. et al. 2014. Mass development of green filamentous algae of the genera Spirogyra and Stigeoclonium (Chlorophyta) in the littoral zone of Southern Baikal. Gidrobiologicheskiy Zhurnal [Hydrobiological Journal] 5: 15-26. (in Russian)

Tomberg I.V. 2008. Transformation of the chemical composition of river waters in the mixing zone with lake waters (a case study of the main tributaries of Lake Baikal). Cand. Sc. Dissertation, Limnological institute SB RAS, Irkutsk, Russia. (in Russian)

Watanabe Y., Drucker V.V. 1999 Phytoplankton blooms in Lake Baikal, with reference to the lake's present state of eutrophication. In: Kawanabe H., Coulter G.W., Roosevelt A.C. (Eds.), Ancient lakes: their cultural and biological diversity. Ghent, Belgium: Kenobi Productions, pp. 217-225. 